6. Beyer C. Klavierkonzert in D-moll. op. 15 // Musiker und ihre Werke. Johannes Brahms. Leipzig, 1897. S. 250-265.

7. Geiringer K. Brahms: His Life and Work. Boston and New York, 1936. 432 p.

\title{
References
}

1. Gulyanitskaya, N. (2009). Comparative studies. In: N. Gulyanitskaya, ed., Methods of the music science. Moscow, pp. 69-84 [in Russian].

2. Merkulov, A. (1985). From observations on sound symbolics. Sovetskaya muzyka, 8, pp. 91-96 [in Russian].

3. Torgan, Y. (1978). Brahms piano concertos in the light of the evolution of this genre in the first half of the XIX century. Extended abstract of $\mathrm{PhD}$ thesis. Kyiv [in Russian].

4. Fomina, N. (2014). Pragmatics of initiation in the works by Sergei Prokofiev. PhD thesis. Kharkiv [in Russian].

5. Tsareva, E. (1986). Johannes Brahms. Moscow [in Russian].

6. Beyer, C. (1897). Klavierkonzert in D-moll. op. 15. In.: Musiker und ihre Werke. Johannes Brahms. Leipzig, pp. 250-265 [in English].

7. Geiringer, K. (1936). Brahms: His Life and Work. Boston and New York [in English].

УДК 78.082 .4

DOI: https://doi.org/10.33643/kmus.2019.58.10

Богдан Решетілов,

аспірант кафедри історії світової музики Національної музичної академії України ім. П. І. Чайковського https://orcid.org/0000-0002-7498-1310 reshebogdan@gmail.com

Bogdan Reshetilov, Postgraduate at the Department of History of World Music, Ukrainian National Tchaikovsky Academy of Music https://orcid.org/0000-0002-7498-1310 reshebogdan@gmail.com

\section{ПАУЛЬ ГІНДЕМІТ. ТЕМА 3 ВАРІАЦІЯМИ «ЧОТИРИ ТЕМПЕРАМЕНТИ» ДЛЯ ФОРТЕПІАНО ТА СТРУННОГО ОРКЕСТРУ: ОСОБЛИВОСТІ ЖАНРУ, КОНЦЕПЦІЯ ЛЮДИНИ}

Статтю присвячено твору Пауля Гіндеміта «Чотири темпераменти», що є жанрово неоднозначним і може трактуватися 3 різних позицій. $€$ аргументи на користь трактовки композиції як балету й концерту. Проте інтонаційно-драматургічний аналіз і розгляд твору в контексті сонатносимфонічного циклу за «концепцією Людини» М. Арановського відкриває нові семантичні вектори. Разом із висвітленням творів інших композиторів, присвячених темі темпераментів людини, особливостей співпраці 3 Л. М'ясіним та ймовірної зацікавленості композитором 
функціональною психологією, все це формує головний результат дослідження - віднаходження нової філософської концепції твору.

Ключові слова: Пауль Гіндеміт, «Чотири темпераменти», концепція Людини, драматургічний аналіз, філософська інтерпретація.

Reshetilov Bogdan. Paul Hindemith. Theme with variations «Four Temperaments» for piano and string orchestra: peculiarities of genre, concept of Human. The theme with variations «Four Temperaments» for piano and string orchestra of $\mathrm{P}$. Hindemith nowadays is very repertoire among pianists, conductors and choreographers, therefore, the careful learning of the new interpretative space of this work makes relevance of the study.

The main objectives of the study - finding fundamentally new genreconceptual edges of the «Four Temperaments» of P. Hindemith; consideration of the period in the history of writing a work in the context of cooperation with L. Massine before the official order of music by $\mathrm{G}$. Balanchine; coverage of the program finalization of the themes of temperaments in the professional music of other composers; intonational-character analysis of the dramaturgy of the work; study of the work from the position of the semantic invariant of the sonata symphonic cycle by M. Aranovsky.

The methodology of this study involves a biographical method that is necessary in determining the circumstances of the composer's life and the specifics of his cooperation with choreographers. A comparative method is used when comparing composite architectonics with the work of P. Hindemith and «The concept of Human» by M. Aranovsky. Intonational-semantic method is used in the study of genre and compositional and dramatic features of «Four Temperaments» by P. Hindemith.

Findings and conclusions. P. Hindemith wrote the essay «The Four Temperaments» as one that can be interpreted from three different positions:

1. As it was the order of G. Balanchine, the composer put some of the specifically stage qualities of the ballet into the music. These include posters goingthrough thematism, multi-edged portrait discovery of characters, suite structure with division into scenes, genre framework of musical material, plastic of melodies.

2. «Four Temperaments» is a repertoire concert for piano and strings. Due to the specificity of the functional relationship between the piano and orchestra, the work acquires a new quality. On the one hand there is a typical concert opposing the soloist and the orchestra, in which the tutti orchestral fragments alternate with solo piano ones. On the other hand - these two participants leave each other space for expression, which appears in rather detailed individual episodes. This self addition parallels the complementarity of the second concert for piano and orchestra by J. Brahms, sometimes called «concert symphony». 
3. Architectonics of the work involves the interpretation of the work in the context of the sonata symphonic cycle, where each part corresponds to the «The concept of Human». One of the keys to the philosophical understanding of this correspondence is the program and methods of working with musical material, where the first part is being, and the other parts are the sides of human consciousness.

It is widely known that the manifestation of temperament in the «pure» form in reality almost does not exist. In practice, there is a symbiosis in various combinations of four temperaments. That is why the composer would not have been satisfied by variant of static reproduction of imagery (character). Only in the movement is the objective deployment of «The concept of Human». It should be added that P. Hindemith did not set the task of reproducing the temporal, territorial or national component of the characteristics. This nonattachment to specific situations brings this concept to the level of eternal nonlocal topics. The four temperaments, as the four hypostases of human, are revealed in three situations - individuality (as one that exists in itself, its «pure» manifestation), interaction (with the world, with other personalities) and deepening (in the essence of one or another temperament, hypertrophy of key qualities). This is a footprint (trace, reflection) of a certain understanding of the composer of the diversity of human nature in general - in the past and in modern times.

Key words: Paul Hindemith, «Four Temperaments», the concept of Human, dramaturgic analysis, philosophical interpretation.

Решетилов Богдан. Пауль Хиндемит. Тема с вариациями «Четыре темперамента» для фортепиано и струнного оркестра: особенности жанра, концепция Человека. Тема с вариациями «Четыре темперамента» для фортепиано и струнного оркестра П. Хиндемита на сегодняшний день является весьма репертуарным произведением среди пианистов, дирижеров и балетмейстеров, поэтому тщательное изучение его нового интерпретационного пространства актуализирует статью.

Цель и задачи статьи - нахождение принципиально новых жанрово-концептуальных граней «Четырех темпераментов» П. Хиндемита; рассмотрение периода в истории написания произведения в контексте сотрудничества композитора с Л. Мясиным еще до официального заказа музыки Дж. Баланчиным; освещение программного среза тематики темпераментов в профессиональной музыке других композиторов; интонационно-образный анализ драматургии произведения; исследование произведения с позиции семантического инварианта сонатносимфонического цикла по М. Арановскому. 
Методология данного исследования предполагает применение биографического метода, который необходим при выяснении обстоятельств жизни композитора и специфики его сотрудничества с балетмейстерами. Компаративный метод применен при сравнении композиционной архитектоники произведения П. Хиндемита и «концепции Человека» М. Арановского. Интонационно-семантический метод использован при исследовании жанровых и композиционнодраматургических особенностей «Четырех темпераментов» П. Хиндемита.

Bbыводы. П. Хиндемит написал произведение «Четыре темперамента» таким образом, что оно может трактоваться с трех разных позиций:

1. Так как это был заказ Дж. Баланчина, композитор заложил в музыку некоторые чисто сценические качества балета. К ним относятся «плакатный» сквозной тематизм, многогранное портретное раскрытие образов, сюитность структуры с делением на сцены, применение жанровых моделей при формировании музыкального материала, пластика мелодизма.

2. «Четыре темперамента» являются репертуарным концертом для фортепиано и струнных. Вследствие специфики функциональных взаимоотношений фортепиано и оркестра произведение приобретает новое качество. С одной стороны, присутствует типичное концертное противопоставление солист-оркестр, в котором туттийные оркестровые фрагменты чередуются с сольными фортепианными; с другой - эти два участника оставляют друг другу пространство для высказывания, что проявляется в достаточно развернутых отдельных эпизодах. В таком взаимодополнении возникает параллель с комплементарностью Второго концерта для фортепиано с оркестром Й. Брамса, который иногда называют «концертом-симфонией».

\section{3. Архитектоника произведения предполагает трактовку} произведения в контексте сонатно-симфонического цикла, где каждая часть соответствует «концепции Человека». Одним из ключей к философскому пониманию такого соответствия становится программность и методы работы с музыкальным материалом, где первая часть - бытие, другие части - стороны человеческого сознания.

Широко известно, что проявления темперамента в «чистом» виде в реальности почти не существует. На практике есть симбиоз четырех темпераментов в различных комбинациях. Именно поэтому П. Хиндемита не устроил бы вариант статического воссоздания образности. Только в движении возможно объективное развертывание «концепции Человека». Следует добавить, что для композитора не было главной задачей создание временной, территориальной или национальной характеристики образов. 
Такая непривязанность к конкретным ситуациям превозносит данную концепцию до уровня вечных нелокальных тем. Четыре темперамента, как четыре ипостаси человека, раскрываются в трех ситуациях и н д и в и ду а ль н ость (как таковая, которая существует сама по себе, ее «чистое» проявление), взаимодействие (с миром, с другими личностями) и углубление (в сущность того или иного темперамента, гипертрофия ключевых качеств). Это является отражением определенного понимания композитором многоликости человеческой природы вообще - в прошлом и в современности.

Ключевые слова: Пауль Хиндемит, «Четыре темперамента», «концепция Человека», драматургический анализ, философская интерпретация.

Я поставив «Чотири темпераменти» в балеті. Але цікаво те, щзо зараз цюю річ Гіндеміта часто грають на концертах. І навіть записують на платівки. Тому щзо він написав якісну музику, хоч і на замовлення. Це й називається-професіоналізм.

Дж. Баланчин [3]

П. Гіндеміт має значний творчий доробок у різноманітних жанрах, серед яких, зокрема, є опери, балети, симфонії, камерно-інструментальні твори, вокальна музика, концерти тощо. Здебільшого твори мають очевидну жанрову визначеність вже в самій назві. Проте «Чотири темпераменти» посідають особливе місце, адже їхні історія написання, композиційна архітектоніка й нетипова програмна образність викликають низку питань щодо трактування жанру.

Твір «Чотири темпераменти» $\epsilon$ вельми знаним на сьогодні. Він виконується з однаково великим успіхом і як концерт для фортепіано та струнного оркестру, і як балет. Починаючи з 1940-х років цей твір посів місце в репертуарі таких видатних виконавців-піаністів, як, наприклад, А. Ведерніков, Б. Каніно (Bruno Canino), Є. Ржанов, Л. Флейшер (Leon Fleisher), С. Франсуа (Samson François), К. Хаскіл (Clara Haskil) та ін. А оригінальна хореографія балетмейстера Дж. Баланчина $\epsilon$ незмінною на сьогодні не тільки в Нью-Йоркському балеті (New York City Ballet), у якому відбулась світова прем'єра, але й у Маріїнському театрі, Канзаському балеті (Kansas City Ballet), балеті в Сіетлі (Pacific Northwest Ballet) тощо. Така виконавська популярність музики П. Гіндеміта дає поштовх до більш ретельного вивчення твору в новому інтерпретаційному просторі, що зумовлює актуальність теми дослідження. До наукової новизни належить висвітлення раніше не застосованих до «Чотирьох темпераментів» аналітичних моделей, результатом яких є новий семантичний погляд на образну драматургію цього твору. 
Мета й завдання cmammi - знаходження принципово нових жанрово-концепційних граней «Чотирьох темпераментів» П. Гіндеміта; розгляд періоду написання твору в контексті співпраці з Л. М'ясіним ще до офіційного замовлення музики Дж. Баланчиним; висвітлення програмного «зрізу», пов'язаного з тематикою темпераментів, у професійній музиці інших композиторів; інтонаційно-образний аналіз драматургії твору; дослідження твору 3 позиції семантичного інваріанту сонатносимфонічного циклу за М. Арановським.

Методологія дослідження включає біографічний метод, який $\epsilon$ необхідним при з'ясовуванні обставин життя композитора та його специфіки співпраці з балетмейстерами; компаративний метод - при порівнянні архітектоніки твору П. Гіндеміта та «концепції Людини» М. Арановського; інтонаційно-семантичний метод - при дослідженні жанрових і композиційно-драматургічних особливостей «Чотирьох темпераментів» П. Гіндеміта.

Точкою відліку в історії написання цього твору є творчий контакт із хореографом Л.М'ясіним, разом 3 яким П.Гіндеміт створив балет «Nobilissima visione» - драматичну й хореографічну інтерпретацію життя святого Франциска Ассізького. Після успішної прем'єри цього твору 1938 року Л. М'ясін вирішив продовжити співпрацю та звернув увагу композитора на живопис П. Брейгеля Старшого. Він замовляє балет у дусі картини «Країна ледарів» i «щось на кшталт фламандського селянства Персефони» ${ }^{1}$. Проте перед початком Другої світової війни композитор переїжджає з Європи до США через цілком зрозуміле побоювання зростання воєнної агресії Третього Рейху. Хоча П. Гіндеміт і був занурений у цю тематику, його творчі взаємовідносини 3 Л. М'ясіним слабшають внаслідок зміни місця проживання та певних організаційних проблем у балетній трупі. Тому можна говорити про те, що що б не написав П. Гіндеміт у період задуму наступного балету для Л. М'ясіна, це могло б стати музичним матеріалом для балету «Чотири темпераменти».

Зустріли композитора в США тепло й надали посади в кількох університетах ${ }^{2}$, де він мав змогу безпечно продовжувати займатися композиторською, педагогічною та науковою діяльністю. Саме в цей час хореограф Дж. Баланчин у вельми цікавий спосіб замовляє П. Гіндеміту музику. «Пам'ятаю, я працював на Бродвеї, у мене водилися деякі грошенята. Справа була, здається, у 1940 році. Після всіляких витрат у мене

\footnotetext{
${ }^{1}$ «...something in the nature of a Flemish peasant Persephone» [8].

${ }^{2}$ Сльський університет (м. Нью-Гейвен, Коннектикут), університет штату Нью-Йорк у м. Баффало тощо.
} 
ще залишилось п’ятсот доларів. Я думав: що мені на ці гроші зробити придбати новий портсигар який-небудь незвичайний, чи що? А потім вирішив: ax! попрошу Гіндеміта написати для мене що-небудь. Гіндеміт каже: “А що Ви хочете?”. Я пояснив - що-небудь для рояля 3 оркестром» [3], - із цих спогадів хореографа стає очевидною відсутність першопочаткової програмної прив'язки твору - своєрідний композиторський карт-бланш. Саме тому в інтерпретаційному просторі цей твір розташований на межі двох жанрів - балет і фортепіанний концерт.

Слід додати, що Єльський університет, у якому працював на той час композитор, спеціалізувався на підготовці фахівців в області точних, природничих та гуманітарних наук. Тому є підстави стверджувати, що програмний підзаголовок «Чотири темпераменти» відображає інтерес П. Гіндеміта до американської наукової школи свого часу, зокрема, до психологічного напрямку функціоналізм ${ }^{1}$ [7, с. 294]. Можливо, ця область зацікавила автора як така, що має великий потенціал щодо синтезу емоційного, образного, вербального начал і хореографічної пластики.

Музичне відтворення людських темпераментів не було програмним відкриттям П. Гіндеміта. I до нього до цієї тематики зверталися такі композитори, як К.Ф.Е. Бах у струнній тріо-сонаті $c$-moll ${ }^{2}$, Й. Штраус (син) у вальсі «Die Sanguiniker» (op. 27)3. Але найбільш масштабним зразком, про який міг знати П. Гіндеміт, є друга симфонія «Чотири темпераменти» данського композитора К. Нільсена, написана 1902 року. Цей композитор звертається до жанрово-композиційної моделі симфонії та застосовує засоби виразності кожної з частин циклу до того чи іншого типу психоемоційного світосприйняття [5, с. 237]. Звісно, темпераментами цікавилися композитори й після П. Гіндеміта: Б. Франкштейн «Temperamento» для струнного квінтету й том-томів (1985), В. Успенський «Темпераменти» для скрипки, тромбона та фортепіано (1989) тощо.

Тематика чотирьох темпераментів $є$ досить плідною для сценічної інтерпретації, оскільки надає широкий інструментарій для роботи. Наприклад, сам Дж. Баланчин разом зі співавтором книги «Сто одна розповідь про великий балет» Д. Мейсоном характеризує балет П. Гіндеміта як «класичний» $\mathrm{i}$ дає йому підзаголовок «танцювальний безсюжетний балет» [7, с. 296]. Тобто трактування програмності балету

\footnotetext{
${ }^{1}$ Функціоналісти вважали необхідним розглядати організм у спільності розуму й тіла, фізичних і психологічних аспектів.

${ }^{2}$ Композитор дотепно відтворив бесіду двох людей - меланхоліка й сангвініка, де кожен хоче «перетягнути» співрозмовника на свою сторону.

33 німецької - «Сангвініки». У даному разі жанрове розкриття теми темпераменту має неконфліктний розважальний характер.
} 
може побудованим на образних чергуваннях або метаморфозах. До того ж концепція різних темпераментів надає можливість багатогранно продемонструвати професійну майстерність виконавців. Тому не дивно, що 1946 року $^{1}$, після довгого очікування (музика була написана П. Гіндемітом ще 1940 року $^{2}$ - всього за місяць після замовлення), сценічна прем'єра балету під натхненною орудою Дж. Баланчина супроводжувалася великим піднесенням публіки.

«Якщо бажаєте, можете цю штуку використати для балету. Але я не хочу, щоб “Чотири темпераменти” грали зараз у концертах. Тому що зараз я пишу в іншому стилі» ${ }^{3}$ [3], - адресований Дж. Баланчину, цей вислів композитора вказує на те, що він не позиціонував тоді твір як інструментально-концертний. Тим не менш твір «Чотири темпераменти» також справедливо завоював місце в репертуарі концертуючих піаністів. Згідно 3 монографією Т. Лєвої та О. Леонтьєвої, «Чотири темпераменти» розглядається саме як перший із двох фортепіанних концертів ${ }^{4}$ [4, с. 247]. I не дивно, бо музика вимагає він виконавця надзвичайної професійної майстерності. Такі засоби виразності, як складна ритміка, суто гіндемітівська багаторівнева поліфонія, стрімкий паралельний рух короткими тривалостями, непрості акордові фактурні рішення тощо висувають до піаніста серйозні технічні вимоги. Тому через цілковиту самодостатність форми неможливо відмовитись від концертного трактування твору. До того ж у творчому доробку композитора на той час вже було багато творів для солюючого інструменту 3 оркестром, серед яких, зокрема, і сім жанрово дотичних до нього «Kammermusik».

Твір «Чотири темпераменти» складається 3 п'яти частин із програмними назвами «Theme», «Melancholy», «Sanguine», «Phlegmatic» $\mathrm{i}$ «Choleric». Музичною моделлю, яка відтворює ідею чотирьох темпераментів, стають варіації. Ця художня «конструкція» реалізує принцип єдності в різноманітті або різноманіття в єдності [5, с. 237]. Форма твору - по трі йн і варіації. У вельми дотепний спосіб П. Гіндеміт вирішив розкрити типи темпераментів: у першій частині відбувається

\footnotetext{
${ }^{1}$ Сценічна прем’єра - 20 листопада 1946 року, м. Нью-Йорк, хореографія Дж. Баланчина.

${ }^{2}$ Інструментально-концертна прем’єра - 3 вересня 1940 року, м. Бостон, соліст Л. Фос (L. Foss), диригент - Р. Бьорджин (R. Burgin).

${ }^{3}$ П. Гіндеміт 1940 року написав іще такі твори: фуги та інші навчальні п'єси для фортепіано; п'єси для фагота й віолончелі; Третю органну сюїту; Концерт для віолончелі з оркестром; Старовинну ірландську пісню для хору з оркестром; Симфонію Es-dur. А згодом, 1942 року, з'явиться знаменитий «Ludus tonalis» для фортепіано.

${ }^{4}$ Другий фортепіанний концерт написано 1945 року.
} 
експозиція трьох тем, а їхнє повторення в кожному наступному розділі твору у видозміненій формі демонструє метаморфози темпераментів.

Перша тема першої частини написана у простій тричастинній формі в тональності in $C$ (Приклад 1). Тема має вокально-розспівну інтонаційну природу, їй властивий розмірений, спокійний рух. У цілому образ цієї теми є узагальненим і безособовим. Такий вид тематизму залишає простір для драматургічних втручань - він $є$ ніби «пластиліном», 3 якого виліплюватимуться інші образи. Друга тема виконується в півтора раза швидше й також написана in $C$. Інтонаційна природа теми $\epsilon$ інструментальною (великий невокальний діапазон, гамоподібні фігури, стрибки тощо). Ця тема складається з двох тематичних елементів (форма - $a$ $b-a-b)$, серед яких перший - стрімкий, синкопований; другий - форшлаговий, скерцозний. Загалом ці елементи є взаємодоповнюючими. Третя тема першої частини написана в далекій у порівнянні 3 першими двома темами тональності - in Es. Це свідчить про намір композитора посилити відокремлення третьої теми, оскільки вона може нагадувати першу тему своєю вокально-баркарольною, часом романсовою інтонаційною природою. Форма третьої теми - $a-a-b-a$, де всі елементи є однорідними.

Нотний приклад № 1

\section{Фрагменти трьох тем першої частини}

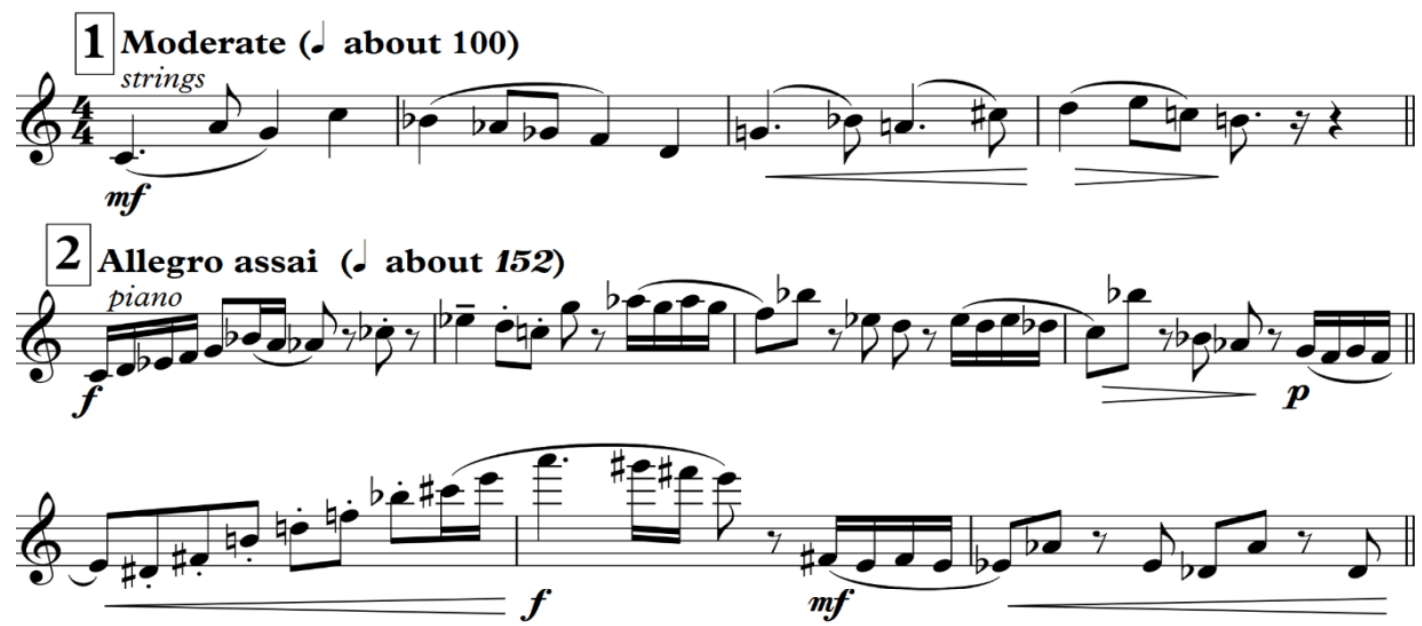

3 Moderate $(\cdot=50-54)$
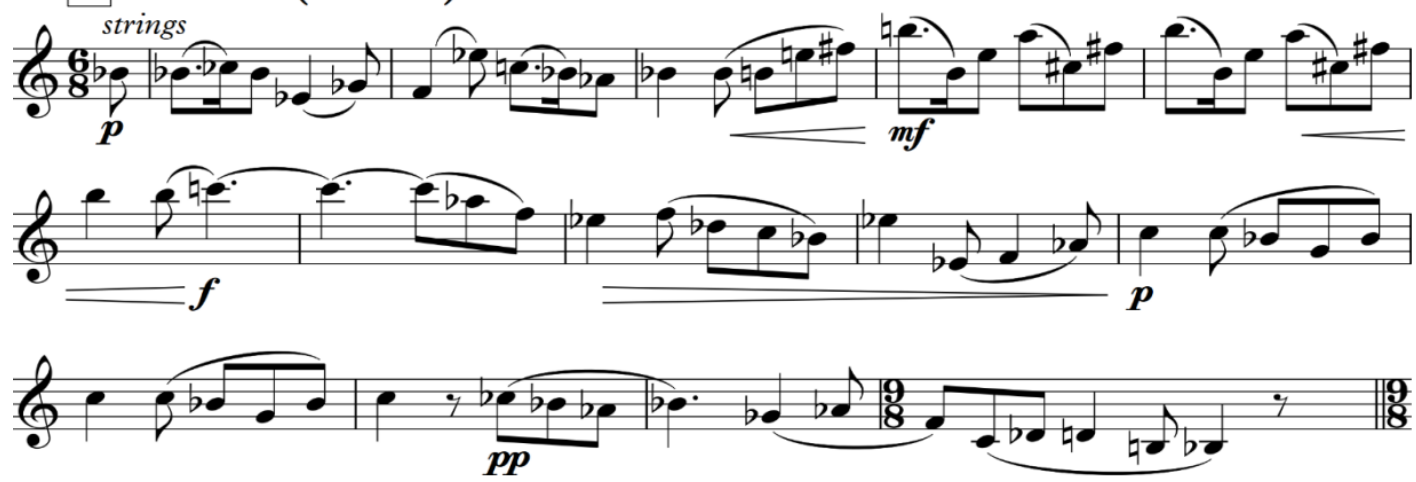
У першій частині відбувається експозиція не тільки основного тематизму, але й трьох образних сфер відповідно до порядку тем: рівновага; дієвість; ліричність. Саме за таким принципом i в такому порядку будується форма наступних частин, кожна 3 яких $\epsilon$ видозміненим повторенням. Так композитор створив певну відправну точку, певну «пр и кладну с и туацію», у яку потрапляє кожен образ.

У другій частині перша тема (тема меланхоліка) - повільна, нестійка, 3 пунктирними ритмами та в інструментальному викладі дуету рояля й солюючої скрипки. Тут створюється атмосфера самотності, інтимності, відмінна від попередньої. Друга тема $з$ такими характеристиками, як темп Presto й динамічний нюанс $p p$ зі скрецозної перетворюється на тривожнотаємничу (відносно першої частини твору). Жанровим рішенням третьої теми стає марш, у якому не залишилося місця вокальній природі тематизму. Ліричність змінюється на протидіючу, конфронтаційну образність. Меланхолік представлений змінами трьох тем таким чином: рівновага - невпевненість, ламкість; скерцозність - тривога; пісенність маршова агресивність.

У третій частині сангвінік продемонстрований максимально узагальнено, у вальсовому жанровому варіанті. Усі тональності тем уперше не збігаються 3 початковими, зокрема, виклад матеріалу перших двох тем відбувається 3 переважанням дієзності, що свідчить про максимальну абстрагованість образу від заданих експозиційних настанов. Унаслідок цього всі три образи трансформуються в життєствердні, безтурботні, 3 танцювальною жанровою основою. Така однорідність характеристики говорить про певну стійкість та цілісність образу.

Перші дві теми флегматика у четвертій частині $\epsilon$ максимально пересічними 3 образністю експозиційного матеріалу: зберігається рівновага першої теми; стрімкість другої теми стає неспішною та легкою. Найбільших метаморфоз зазнає третя тема - вокальна інтонаційна основа раптом обертається неспішною дводольною танцювальністю.

У п'ятій частині теми холерика темпово нестабільні, клаптикові. Рівноважна тема 3 першої частини стає імпровізаційно-спонтанною, нестримною. Риси скерцозності другої теми посилюються. Третя тема крізь типове для неї поглиблення в ліричну сферу стає майже екзальтованою. Все вищеперелічене можна узагальнити в одній таблиці (Приклад 2). 
Приклад № 2

Метаморфози й переінтонування тем у «Чотирьох темпераментах» П. Гіндеміта згідно з авторськими темповими позначеннями, жанровими, тональними та образними характеристиками

\begin{tabular}{|c|c|c|c|}
\hline $\begin{array}{l}\text { Частина, } \\
\text { темперамент }\end{array}$ & $\begin{array}{l}\text { Перша тема, } \\
\text { сфера рівноваги }\end{array}$ & $\begin{array}{l}\text { Друга тема, } \\
\text { сфера дієва }\end{array}$ & $\begin{array}{c}\text { Третя тема, } \\
\text { сфера лірична }\end{array}$ \\
\hline $\begin{array}{c}\text { I ч. } \\
\text { Theme }\end{array}$ & $\begin{array}{l}\text { 4/4, in C, Moderate q. 100 } \\
\text { Розмірена, спокійна, } \\
\text { узагальнена }\end{array}$ & \begin{tabular}{|l}
$/ 4$, in C, Allegro \\
assai q. 152 \\
Стрімка, скерцозна \\
\end{tabular} & $\begin{array}{l}\text { 6/8, in Es, Moderate } \\
q .=50-54 \\
\text { Пісенна, баркарольна }\end{array}$ \\
\hline $\begin{array}{c}\text { II ч. } \\
\text { Melancholy }\end{array}$ & $\begin{array}{l}\text { 9/8, in C, Slow q. 56 } \\
\text { Нестійка, «ламка» }\end{array}$ & $\begin{array}{l}\text { 12/8, in C, Presto } \\
\text { q. } 92 \\
\text { Тривожна, } \\
\text { неспокійна }\end{array}$ & $\begin{array}{l}\text { 4/4, in Es, Slow march } \\
q .=46-50 \\
\text { Похмура, маршова }\end{array}$ \\
\hline $\begin{array}{c}\text { III ч. } \\
\text { Sanguine }\end{array}$ & \multicolumn{3}{|c|}{$\begin{array}{l}\text { 3/4, Waltz, h.=63, in E, in Cis, in G. Цілісний вальсовий образ. Стійкість } \\
\text { до змін. Максимальна абстрагованість. }\end{array}$} \\
\hline $\begin{array}{l}\text { IV ч. } \\
\text { Phlegmatic }\end{array}$ & \begin{tabular}{|l} 
4/4, in C, Moderate \\
$q .=96-100$ \\
Наближена до звучання в \\
першій частині, \\
неспішна
\end{tabular} & $\begin{array}{l}\text { 12/8, in Cis, } \\
\text { Allegretto q. }=100 \\
\text { Стримана, легка }\end{array}$ & $\begin{array}{l}2 / 4, \text { in Es, Allegretto } \\
\text { scherzando q.=100 } \\
\text { Дводольна } \\
\text { танцювальність }\end{array}$ \\
\hline $\begin{array}{l}\text { V ч. } \\
\text { Choleric }\end{array}$ & $\begin{array}{l}\text { 4/4, in C, Vivace, Lento } \\
\text { accel. Середнього темпу } \\
\text { немає - він постійно } \\
\text { змінюється. } \\
\text { Фрагментарність, } \\
\text { нестримність }\end{array}$ & $\begin{array}{l}2 / 4, \text { in A, Vivace } \\
\text { q.=144-152 } \\
\text { Рухлива, } \\
\text { скерцозно- } \\
\text { невпинна }\end{array}$ & $\begin{array}{l}\text { 12/8, in C, Appasionato } \\
q . \sim 72 \\
\text { Посилення образності } \\
\text { внутрішніх переживань, } \\
\text { гіпертрофованість }\end{array}$ \\
\hline
\end{tabular}

У такому контексті перша тема $є$ своєрідним «мірилом» кожного 3 чотирьох темпераментів. Саме у варіаціях на першу тему з другої до п'ятої частини кожен темперамент розкриває свої ключові якості. Друга тема в експозиції є дієвою та спонукає до взаємодії. Третя тема, з ії ліричним та особистісним складом відтворює гіпертрофовані якості темпераментів. Відтак функціонально три образні сфери можна позиціонувати, відповідно, як: нейтральну; екстатично-екстравертну; інтровертну (Приклад 3).

Приклад № 3

\section{Загальний образно-драматургічний план «Чотирьох темпераментів» Пауля Гіндеміта}

Екстравертність, гіпертрофованість образу

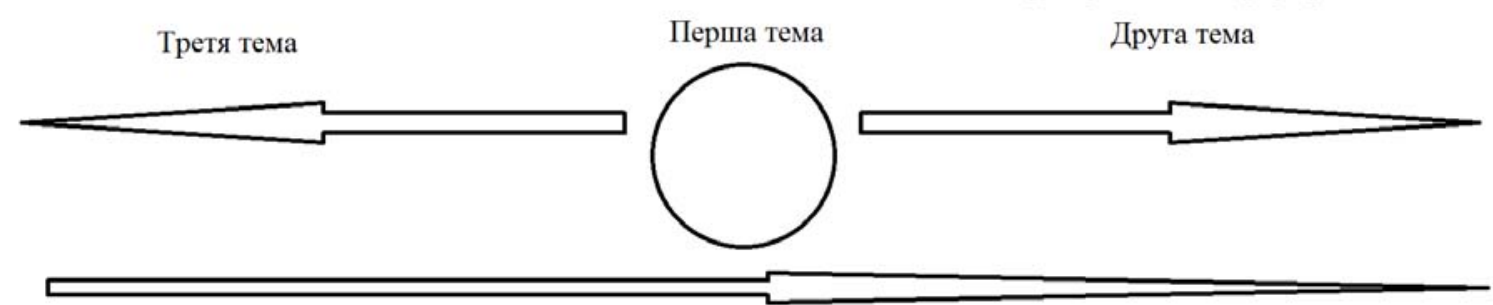


Обрана композитором архітектонічна модель формує образну драматургію таким чином: кожен темперамент розкривається 3 трьох сторін унаслідок переінтонування тем першої частини. Така «плакатна» структура «Чотирьох темпераментів» може трактуватися кількома способами. Першим варіантом трактовки форми є, безперечно, варіації: це очевидно 3 авторської назви твору та методу роботи 3 музичним матеріалом. Другий варіант - сюїта: програмність такого складу вказує на чітке розмежування частин. Третій варіант - сонатно-симфонічний цикл. Сам принцип варіаційного методу 3 акцентованими моментами переінтонування в даному випадку симфонізує концерт та робить його монолітним, як у випадку сонатно-симфонічного циклу.

Спираючись на «концепцію Людини» М. Арановського щодо загальної картини відповідності між семантичним інваріантом кожної частини сонатно-симфонічного циклу та її структурною складовою [1, с. 27], можна провести паралель між чотирма «типами» людини за М. Арановським та чотирма темпераментами у творі П. Гіндеміта (Приклад 4).

Приклад № 4

Порівняльна таблиця архітектоніки «Чотирьох темпераментів» П. Гіндеміта й семантичного інваріанту сонатно-симфонічного циклу за М. Арановським

\begin{tabular}{|c|c|c|c|c|}
\hline $\begin{array}{c}\text { Тип } \\
\text { темпераменту }\end{array}$ & \multicolumn{2}{|c|}{ «Концепція Людини» } & $\begin{array}{c}\text { Частини за } \\
\text { М. Арановським }\end{array}$ & $\begin{array}{c}\text { Частини у творі } \\
\text { П. Гіндеміта }\end{array}$ \\
\hline Безособовість & Прикладна ситуація, умови & - відсутня & I частина \\
\hline Холерик & $\begin{array}{c}\text { Homo } \\
\text { agens }\end{array}$ & $\begin{array}{c}\text { Людина, } \\
\text { що діє }\end{array}$ & I частина & V частина \\
\hline Флегматик & $\begin{array}{c}\text { Homo } \\
\text { sapiens }\end{array}$ & $\begin{array}{c}\text { Людина } \\
\text { розумна }\end{array}$ & II частина & IV частина \\
\hline Меланхолік & $\begin{array}{c}\text { Homo } \\
\text { ludens }\end{array}$ & $\begin{array}{c}\text { Людина, що } \\
\text { грає }\end{array}$ & III частина & II частина \\
\hline Сангвінік & $\begin{array}{c}\text { Homo } \\
\text { communis }\end{array}$ & $\begin{array}{c}\text { Людина } \\
\text { суспільна }\end{array}$ & IV частина & III частина \\
\hline
\end{tabular}

Як видно, порядок частин у концепції М. Арановського не зовсім збігається 3 композиційною архітектонікою твору П. Гіндеміта ${ }^{1}$. Композитор скористався оригінальною структурною моделлю, яка більш багатогранно та об’єктивно відтворює програму даного твору.

\footnotetext{
${ }^{1}$ Більше спільного виявляється скоріше в Другій симфонії К. Нільсена. Можна сказати, що К. Нільсен пішов прямим шляхом у контексті структурного відтворення темпераментів: чотири темпераменти - відповідно, чотири частини симфонії, кожна 3 яких $€$ відтворенням одного темпераменту. Проте П. Гіндеміта не влаштував такий підхід до цієї проблематики.
} 
Аби висвітлити цю розбіжність, треба пригадати одну 3 головних характерних рис, притаманних неокласицизму: в музиці стає небажаним будь-який прояв суб'єктивного начала. Композитори, зокрема й П. Гіндеміт, ратують за об'єктивність висловлювання, його ясність та організованість [2, с. 145].

Вочевидь, у контексті теми темпераментів П. Гіндеміт пропонує самобутню «концепцію Людини», яку яскраво демонструє здійснений інтонаційно-образний драматургічний аналіз. Тобто варіації «Чотири темпераменти» П. Гіндеміта можуть бути трактованими не тільки як балет або фортепіанний концерт, а ще й у рамках сонатно-симфонічного. Адже ймовірна зацікавленість композитора функціональною практичною психологією стала поштовхом до переосмислення «концепції Людини» та iii темпераментної багатогранності.

Висновки. П. Гіндеміт написав твір «Чотири темпераменти» як такий, що може трактуватися з трьох різних позицій.

1. Оскільки це було замовлення Дж. Баланчина, композитор заклав у музику певні суто сценічні якості балету. До них належать: «плакатний» наскрізний тематизм, багатогранне портретне розкриття образів, сюїтність структури з поділом на сцени, застосування жанрових моделей, пластика мелодизму.

2. «Чотири темпераменти» $\epsilon$ репертуарним концертом для фортепіано та струнних. Унаслідок специфіки функціональних взаємовідносин фортепіано та оркестру твір набуває нової якості. 3 одного боку, присутнє типове концертне протиставлення соліст-оркестр, у якому туттійні оркестрові фрагменти чергуються з сольними фортепіанними; 3 іншого - ці два учасника залишають один одному простір для висловлювання, що проявляється в досить розгорнутих окремих епізодах. Це проводить паралель із комплементарністю Другого концерту для фортепіано 3 оркестром Й. Брамса, який іноді називають «концертсимфонія». У загальній практиці далеко не кожен твір для оркестру 3 розгорнутою фортепіанною партією можна вважати типовим концертом. Прослідковується це, наприклад, у Камерній симфонії для 12 інструментів Дж. Енеску, де фортепіано органічно співіснує в загальному музичному просторі без драматургічного переходу на перший план [6, с. 58-59].

3. Архітектоніка твору передбачає його трактування в контексті сонатно-симфонічного циклу, де кожна частина відповідає «концепції Людини». Одним із ключів до філософського розуміння такої відповідності стає програмність і методи роботи з музичним матеріалом, де перша частина - буття, інші частини - сторони людської свідомості. 
Широко відомо, що проявів темпераменту в «чистому» вигляді в реальності майже не існує. На практиці є симбіоз чотирьох темпераментів у різних комбінаціях. Саме тому П. Гіндеміта не влаштував би варіант статичного відтворення образності. Тільки в русі можливе об'єктивне розгортання «концепції Людини». Слід додати, що неприв'язаність до конкретних ситуацій (час, територія, національність тощо) підносить дану концепцію до рівня вічних нелокальних тем. Чотири темпераменти, як чотири іпостасі людини, розкриваються у трьох ситуаціях індивідуальність (як така, що існує сама по собі, їі «чистий» прояв), взаємодія (зі світом, 3 іншими особистостями) та заглиблення (у сутність того чи іншого темпераменту, гіпертрофія ключових якостей). Це є відбитком певного розуміння композитором багатоликості людської природи взагалі - у минулому і в сучасності ${ }^{1}$.

1. Арановский М. Симфонические искания : Исследовательские очерки. Ленинград : Сов. композитор. Ленингр. отд-ние, 1979. 287 с.

2. Варунц В. Цикл «Kammermusik» (к вопросу о неоклассицизме П. Хиндемита) // Пауль Хиндемит 1895-1963: Статьи и материалы / ред.-сост. И. Прудникова. Москва : Сов. композитор, 1979. С. 143-178.

3. Волков С. Страсти по Чайковскому : Разговоры с Джорджем Баланчиным. Москва : Независимая газета, 2001. $336 \mathrm{c.}$

4. Левая Т., Леонтьева О. Пауль Хиндемит : Жизнь и творчество. Москва : Музыка, 1974. $449 \mathrm{c}$.

5. Сальникова М. Художественное воплощение темперамента в музыке // Известия Российского государственного университета им. А. И. Герцена. Аспирантские тетради. Санкт-Петербург, 2008. № 26(60). C. 236-238. URL: https://lib.herzen.spb.ru/media/magazines/contents/1/26(60)/salnikova_26_60_236_238.p df (дата обращения: 30.03.2019).

6. Решетілов Б. Композиційний вплив камернізації як один з факторів становлення драматургічного процесу у концертних творах для фортепіано 3 оркестром XX сторіччя // International Scientific and Practical Conference World Science. 2018, № 12(40), Р. 56-59.

7. Чиликина Н. «Четыре темперамента» П. Хиндемита - Дж. Баланчина в зеркале практической психологии своего времени // Культура: открытый формат - 2013 (библиотековедение, библиографоведение и книговедение, искусствоведение, культурология, музееведение, социокультурная деятельность) : сб. науч. ст. Минск, 2013. C. 294-297.

8. Corleonis A. Paul Hindemith, theme and variations, «Die vier temperamente» (The four temperaments) // Fanfare magazine. 2007. URL: http://americansymphony.org/theme-andvariations-die-vier-temperamente-the-four-temperaments-1940/ (access date: 30.03.2019).

\footnotetext{
${ }^{1}$ Багатотемність у «Чотирьох темпераментах» П. Гіндеміта може бути трактована як розмаїта картина світу, в якій окреслене місце людини.
} 


\title{
References
}

1. Aranovskii M. (1979). Symphonic Quest. Leningrad: Sovetskii kompozitor [in Russian].

2. Varunts V. (1979). The Cycle «Kammermusik» (to the question of Neo-Classicalism by P. Hindemith. In: V. Varunts, ed., Paul Hindemith. Articles and materials. Moscow, Sovetskii kompozitor, pp. 143-178 [in Russian].

3. Volkov S. (2001). Passion for Tchaikovsky. Talks with George Balanchine. Moscow: Nezavisimaia gazeta [in Russian].

4. Levaia T., Leonteva O. (1974). Paul Hindemit. Life and art. Moscow: Muzyka. [in Russian].

5. Salnikova M. (2008). Artistic incarnation of temperament in music. Izvestiia Rossiiskogo gosudarstvennogo universiteta im. A. I. Gertsena, [online] pp. 236-238. Available at: https://lib.herzen.spb.ru/media/magazines/contents/1/26(60)/salnikova_26_60_236_238.p df [Accessed 30 March 2019] [in Russian].

6. Reshetilov B. (2018). Compositional impact of camernisation as one of factors of formation of dramatic process in concert works for piano with orchestra of XX century. World Science, 12(40) Vol. 2, pp. 56-59 [in Ukrainian].

7. Chilikina N. (2013). «Four temperaments» by P. Hindemith - J. Balanchine in the mirror of practical psychology of his time. In: N. Chilikina, ed., Culture: open format. Minsk: BGUKI, pp. 294-297 [in Russian].

8. Corleonis A. (2007). Paul Hindemith, theme and variations, "Die vier temperamente" (The four temperaments). [online] American symphony orchestra. Leon Botstein, Music director. Available at: http://americansymphony.org/theme-and-variations-die-viertemperamente-the-four-temperaments-1940/ [Accessed 30 March 2019] [in English].

УДК 781:00267:362

DOI: https://doi.org/10.33643/kmus.2019.58.11

\author{
Олена Марценківська, \\ кандидат мистеитвознавства, доцент, \\ завідувач відділення денної форми навчання \\ Київської муніциипальної академії музики ім. Р. М. Глісра \\ https://orcid.org/0000-0003-1732-5787 \\ martolenka@ukr.net \\ Olena Martsenkivska, \\ Ph.D. in Arts, Associate Professor, \\ Head of the Department of education, \\ R. Glier Kyiv Municipal Academy of Music \\ https://orcid.org/0000-0003-1732-5787 \\ martolenka@ukr.net
}

\section{НЕОФОЛЬКЛОРИЗМ ЯК РОМАНТИЧНА ТЕНДЕНЦІЯ В МУЗИЦІ БОРИСА ЛЯТОШИНСЬКОГО}

У дослідженні увагу спрямовано на виявлення національностильової константи фортепіанної та камерно-інструментальної творчості 